the ancient seas, and assembled an appalling mass of very raw data on which he has leaped, with the agility of Raphael Pumpelly's mouflon, from assumption to assumption to heights of speculation where few would care to follow. But Ma's basic idea that annual growth-rates can be determined for many fossil corals appears to be sound.

Others have concluded that annulations or related internal variations in some Palæozoic corals have an annual basis, but no experiments have been undertaken on living corals to determine directly whether or not there is a causal relation between such annulations and annual variations in temperature or other factors. I do not know why such an obvious and simple test has not yet been attempted. There are some experimental data on allometric and volumetric growth-rates but these have little bearing on the problem of annulations, nor do these data tell, or are likely to tell, much more than: (1) that reef corals grow more rapidly in warmer waters; (2) that some corals grow faster than others. There is some evid. ence that fluctuations in nutrient supplies and reproductive activity have little or no effect on the overall growthrate of corals.

We must now make an act of faith and assume that the major annulations on corals represent annual growth increments or varves. This, however, is of no direct value in geochronometry, even though it can thereby be shown that some large fossil coral colonies endured for a couple of hundred years, and that some living colonies of reef corals have been growing for the past thousand years or so. There is nothing in these values to orient them in time. A closer look at certain coral structures is necessary.

A number of people have noticed the fine ridges (Figs. 3 and 4 ) on the surface of the coral epitheca, a fundamental skeletal structure in tabulates, rugosans, and scleractinians, the basic material not only of the exterior of the corallum but in various guises as septa and dissepiments. Whenever epitheca is present and unmodified these ridges are present, although in many fossil specimens they are obliterated by post-mortem wear. The ridges are parallel to the growing edge of the corallum and are tacitly accepted as growth increments variously termed striæ, ridges and growth-lines. I cannot find, however, that anyone has concerned himself with their significance in growth-time. They clearly indicate regular variations in the rate of calcium carbonate secretion, but what is the relation of these to the passage of time? Hourly, daily, circadian, weekly, lunar monthly, periodic reproductive activity, yearly ?

I submit that they indicate daily or circadian variation in skeletal deposition, and there is some slender evidence in this direction. Physiological studies on calcium carbonate secretion in recent corals, first made some years ago by Kawaguti and Sakumoto ${ }^{6}$, and recently and more elegantly by Goreau ${ }^{7}$, who used the isotopo calcium45 , show that in reef corals the rate of calcium carbonate uptake in coral tissues falls at night or in darkness and rises during the day, but the reflexion of this in the skeleton has not yet been investigated. A much less-sophisticated approach would be to compare the number of ridges with the annual growth-rate; but this has not been directly tried on living corals in the field. I have tested it indirectly on one or two recent corals the annual linear growth-rate of which is fairly well known, and to my gratification found that the number of ridges on the epitheca of the living West Indian scleractinian Manicina areolata (Fig. 5) hovers around 360 in the space of a year's growth. This strongly suggests, subject to experimental confirmation, that the growth-lines are diurnal or circadian in nature. It may be noted in passing that they may provide a much more sensitive caliper for measurement of annual growth-rates than the larger yearly annulations.

The next step, of course, is an attempt to determine the number of growth-lines per annum in fossil corals. Here, as is usually the case, hypothesis is easier than practice. Few fossil corals are sufficiently well preserved to show clearly the supposed diurnal growth-lines, and it is not easy to determine the annual rate. In epithecate recent corals the growth-lines are commonly abraded or corroded even before death of the polyp. The best of the limited fossil material I have examined so far is from the Middle Devonian of New York and Ontario, especially specimens of Heliophyllum, Eridophyllum (Fig. 6) and Favosites. Diurnal and annual growth-rates vary in the same individual, adding to the complexity, but in every instance there are more than 365 growth-lines per annum, usually about 400 , ranging between extremes of 385 and 410. It is probably too much, considering the crudity of these data, to expect a narrower range of values for the number of days in a year in the Middle Devonian; many more measurements will be necessary to refine them.

A few more data may be mentioned: Lophophyllidium. from the Pennsylvanian (Conemaugh) of western Pennsylvania gave 390 lines per annum, and Caninia from the Pennsylvanian of Texas, 385. These results imply that the number of days a year has decreased with the passage of time since the Devonian, as postulated by astronomers, and hence that values of the isotopic dates of the geophysicists agree well with the astronomical estimates of the age of the Earth. It is not claimed that coral growth proves that either is right; but it is suggested that palæontology may well be able to supply a third stabilizing, and much cheaper, clue to the problem of geochronometry, and that further search for diurnal or circadian records in groups other than corals may result in strengthening this weak anthozoan prop.

${ }^{1}$ Munk, W. H., and MacDonald, G. L. F., The Rotation of the Earth, 250 (Cambridge Univ. Press, 1960)

' Kulp, J. L., Seience, 133, 1105 (1961).

${ }^{3}$ Whitfield, R. P., Bull. Amer. Mus. Nat. Hist., 10, 463, Pl. 24 (1898).

${ }^{4}$ Vaughan, T. W., J. Washington Acad. Sci., 5, 597 (1915).

${ }^{5} \mathrm{Ma}$, T. Y. H., Proc. Imp. Acad. Tokyo, 10, 353 (1934).

F Kawaguti, S., and Sakumoto, D., Bull. Oceanogr. Inst. Taiwan, 4, 65 (1948).

7 Goreau, 'T. F., Biol. Bull., 116, 59; 117, 239 (1959).

\title{
OBITUARIES
}

\section{Prof. H. Graham Cannon, F.R.S.}

Herbert Graham Cannon, Beyer professor of zoology in the University of Manchester, died in St. Bartholomew's Hospital on January 6 at the age of sixty-five. He had been in poor health for some time.

Born in London, Graham Cannon was educated at Wilson's Grammar School, Camberwell, and Christ's College, Cambridge. Having suffered compound fractures of his wrists during a fall in his youth, he was declared unfit for military service, and on graduation in 1918 became biologist to the then Board of Fisheries. A brief period of research at Cambridge soon followed, and in 1920 he was appointed demonstrator, and later lecturer, in zoology in the Imperial College of Science and Technology. In 1926 he became professor of zoology in the University of Sheffield, and in 1931 Beyer profossor of zoology in the University of Manchester. He was elected. a Fellow of the Royal Society in 1935 .

Graham Cannon's early zoologieal work, influenced by Doncaster, concerned the spermetogenesis of lice and the nature of the centrosomal force, but he soon turned to an active interest in tho Crustacoa, which was to last for the greater part of his life. A.t first his work consisted of 
embryological and anatomical studies on Cladocera and Conchostraca, but in 1926 he published a paper on the feeding of an ostracod, Pionocypris, which was the first of a long series of detailed investigations into the complex filtratory feeding mechanisms found in a wide range of Crustacea. He recognized clearly the essential functional components of these mechanisms, describing current producing, filtering, scraping, and transporting limbs, and illustrated them with minute accuracy. The small size of many of these animals, and the difficulty of direct observation of feeding currents, compelled him to rely in large measure on deduction based on the details of structure. His strong interest in functional morphology generally clearly arises from these researches. Papers on feeding mechanisms were followed by a return to internal anatomy, and outstanding papers were those on the ostracods Doloria and Gigantocypris and the cirripede Lithotrya. In spite of the injuries to his wrists, Cannon showed great skill in fine dissection, and became a zoological artist of distinction. His early papers show the steady development of his technique, and by 1930 his illustrations could truly be described as unequalled. Furthermore, he had the ability to communicate his skill to others, and zoologists generally profited greatly by his publication of a book on methods of drawing and illustration.

In 1948 Graham Cannon was president of Section D (Zoology) of the British Association for the Advancement of Science, and his presidential address on undergraduate zoology marked the beginning of a new interest. From this time on he frequently wrote and spoke on educational matters, and rebelled against increasing specialization in teaching in schools and universities. $\mathrm{He}$ turned this interest to practical account by serving on the Northern Universities Joint Matriculation Board, and played an active part in the development of the University of Keele.

Towards the end of his life Cannon became increasingly occupied with thinking and writing on the relationship betwoen Lamarckian and Mendelian inheritance, an interest which clearly had its origin in his work on crustacean feeding mechanisms. He came to hold the view that tho fundamental property of protoplasm is its ability to adjust itself to changes in the environment always in the manner optimum to its survival, and that inheritance by the mechanism of the Mendelian gene complex was to be regarded as a later addition to this fundamental property.

In addition to his research and teaching, Graham Cannon played a full part in University administration. He undertook in Manchester periods of office as dean of the Faculty of Science and as pro-vice-chancellor, and was for many years chairman of the Manchester Museum. Ho served on the Council of the Marine Biological Association, and was well known as an examiner in the University of London. His range of interests was wide, and embraced such diverse interests as music, angling in his early years, cookery, and practical building. But his overriding passion was his love of Japanese objects of art, particularly swords and their furnishings. He was always ready to talk on this topic, publicly or privately, with enthusiasm and understanding.

As a man, Graham Cannon was direct in speech and expressed his views forcibly. He did not easily accept compromise. But thoso who knew him well saw a genial and kindly scholar who took a real interest in his students and staff. They will remember him with gratitude and affection. Their sympathy and that of his friends will go out to his wife and sons and daughters. R. DenNelL

\section{Mr. A. D. Cotton, O.B.E.}

Arthur Disbrowe Cotton, who for nearly sixty years was closely connected with the affairs of the Royal Botanic Gardens, Kew, died, after a long spell of ailing health, at Hertford, on December 27, 1962, at the age of eighty-three. He was born in London on January 15 ,
1879, and received his early education at King's College School, London. During his schoolboy days he developed a strong interest in the British flora, and he built up a considerable collection of pressed plants. His first botanical tuition was received from lectures arranged at Chelsea Physic Garden by J. B. Farmer, and these may well have fostered his liking for gardens and garden plants, an attachment which remained and indeed increased throughout his career. At one time Cotton seems to have determined on a career in horticulture, and he undertook three years' practical training which led to a first-class certificate in the Royal Horticultural Society's general examination.

Later, he decided to follow botany as a vocation, and to this end he spent three years at the Royal College of Science, London, where, under the influence of J. B. Farmer, he specialized in the study of the lower plants. In 1902 he obtained his first post at Owens College, Manchester, where he became an assistant lecturer and, under the influence of $O$. V. Darbyshire, became interested in fungi and did some research on orchid mycorrhiza. 'Two years later he entered Government service as an assistant in the Herbarium at Kew under George Massee, the distinguished mycologist. His general duties and research were mainly concerned with the algae, but he also worked with the fungi and lichens, and during this period he published several papers on these groups including his very important contribution to algal ecology in the Clare Island Survey. In 1915, Cotton was placed in charge of advisory services and research on plant diseases in a new laboratory installed at Kew, and indeed he was the first plant pathologist to be appointed in Government service in Great Britain. The laboratory which he initiatod was later transferred to Harpenden and has become the Plant Pathology Laboratory of the Ministry of Agriculture, Fisheries and Food. Cotton's continuing interest in mycology is reflected in his sixty years' membership of the British Mycological Society of which he was president in 1913.

Cotton returned to Kew in 1922 when he succeeded Otto Stapf as the keeper of the Herbarium and Library, a post he held until his retirement in 1946. This was a period of active development in the Herbarium with an ever-increasing flow of material to be identified, incorporated and distributed, and about a million specimens were added to the collections during Cotton's keepership. While he retained his interest in the algae and fungi, he turned more to the study of flowering plants. He became an expert on the cultivated lilies, published a number of papers on this attractive group, and largely wrote the botanical text of the Supplement to Elwes' Monograph of the Genus Lilium of which latterly he was joint author. For a short timo he was editor of Curtis's Botanical Magazine, and for this and other services to horticulture he was awarded the Victoria Medal of Honour by the Royal Horticultural Society. Cotton attended the meeting of the British Association in South Africa in 1929 and during his return journey visited Kilimanjaro. The extraordinarily bizarre vegetation of the alpine slopes fired a new interest and he undertook a critical study of the arborescent species of Senecio of the East African mountains. One species which he collected on Kilimanjaro bears his name.

He became a Fellow of the Linnean Society in 1902 , served for several periods on the Council and was president during 1943-46. In 1934 he was awarded an O.B.E. Cotton was a man of gentle, unassuming manner who will be remembered gratefully by all who had the pleasure of his friendship as a genial, kind and obliging man.

George Taylor

\section{Prof. Karel Hrubý}

Prof. Karel Hrubý, professor of geneties in the Charles University in Prague, died in a motor-car accident in Jihlava on December 10, 1962. He was one 